\title{
Blue - Ocean Strategy: The Strategic Logic of High Growth for Small and Medium Enterprises in Nigeria.
}

\author{
${ }^{1}$ Dr. Ohimai Friday Eboreime (Ph.D), ${ }^{2}$ Dr. Eleazar Chibuzor Gbandi (Ph.D) \\ ${ }^{1,2}$ Department Of Business Administration, Benson Idahosa University, Benin City, Edo State, Nigeria.
}

\begin{abstract}
In the 2P' Century, businesses, especially small and medium enterprises (SME,) face high Complexity and competitiveness. In order for the Less Developed Countries (LDC,), such as Nigeria in easily industrialize; they need to do this through the development of the SMEs, which should be strategically positioned to achieve this goal. This paper is aimed at exposing the modern management techniques of "blueocean" strategy, which enables SME's in LDCs to look beyond the traditional fierce competitors' boundaries of large companies (especially the multinational companies) to achieve high growth. After an exploratory analysis of these strategies, this is paper conclude that applying the "blue-ocean" strategies of breakthrough by SMEs in form of niching and customization, offer them opportunities to compete with larger companies and meet up with global competitiveness. These strategies have been successfully implemented in Europe, U.S and especially the Emergency Asian Countries of Japan, South Korea, China, India, and many others. in Nigeria, with vast untapped resources, the "blue-ocean" strategies will be suitable for implementation and managing SMEs to compete with larger companies and to achieve global competitiveness is however recommended that the Federal Government of Nigeria throng/i its 'Central Banks and SME agents should substantially finance the SMEs to enable their managers to implement the "blue-Ocean" strategies to achieve the goals of high growth and global competitiveness
\end{abstract}

\section{Introduction}

One of the concerns of policy makers regarding the industrial sector of developing economies is that it is riskily to invest or finance a business enterprise because they cannot meet up with large companies, especially, the Multi-National Companies (MNCs). They blinder that the SMEs will not be strong enough to sustain development in developing countries. In Nigeria, this perception has been manifested especially in the development of the petroleum and power sectors with huge investment, which are now moribund. The fact is that in the developing economies, as Nigeria, with low investment capital and technology, there is the need to imbibe the orientation of the potentials of massive investment in SMEs and using the appropriate strategies, such as "blue-ocean strategy" to boost a rapid "take-off" of the industrial sector, as was done by the U.S.A, European countries and recently the Emerging Asian economies.

The objective of this paper is to expose and explore the virtues of the modern strategy of "blue-ocean thinking" as a veritable logic of breakthrough and high growth for SMEs, which has been designed and implemented in the past by industrialized countries. In Nigeria, with vast untapped resources and market opportunities, there are many investment opportunities for SMEs to apply the blue-ocean strategies.

\section{Concepts And Theoretical Framework}

The concept of small business has been defined differently by different bodies and countries. As regards the number of people employed and total capital investment, in Nigeria it is about 50 full time workers and 2,000,000 capital investment, in Uganda, 5-50 full time worker and U.S $\$ 5,000$ - US\$50,000, while in U.S.A., less than 500 workers and US\$1 million capital investment, and in European Union, up to 250 workers. (Waswa Balunywa, 2009).

In recent years, small and medium scale enterprises (SME) is now emphasized in Nigeria as in U.S.A. and other industrialized economies, in order to give the concept of small scale enterprises wider dimension, capital investment and operations. This is aimed at solving the problems of size, quality, supply chains, logistics and technological innovations (for SMEs). In Nigeria, in 2009, the Bankers' Committee fixed the maximum asset base as $\mathrm{N} 1.5$ billion with no lower or upper limit of staff.

The theoretical framework of this study is anchored on the view by Weintruab (2001) that small companies, through "niching" or focused marketing, have the opportunity to compete with their limited resources on serving the niches, which are overlooked by larger companies and thereby make more profit than larger competitors. Niching and focussed marketing are essential ingredients of blue-ocean strategies in business.

Davidson (2002) also established that many small companies start as niches to get a Foothold against larger and more resourceful competitors, and then grow into broader competitors. 
In addition, Kotler and Armstrong, (2004) proposed that the low cost of setting shop on internet today makes it even more profitable to serve seemingly minuscule niches. Small businesses in particular, are realizing riches from serving small niches on the "web" for example, "Webpreneur", a small web, has achieved "astonishing results" while internet giants like Amazon.com "have yet to even realize consistent profits".

\section{Dealing With Competition By Small Businesses}

Generally dealing with competition requires a good understanding of the competitors, the environment, their status, objectives, strategies their strengths and weaknesses. In dealing with competition, Porter (1990) identified five forces that determine the intrinsic long-run attractiveness of market or market segment. These are, the threat of intense segment rivalry, threat of new entrants, threat of substitute products, threat of buyer's growing bargaining power and threat of suppliers' glowing bargaining power. The status of competitors have to be known- whether "market leader" with large store of the market, "market challenger" and "market follower" with average shares of the market and the "market nicher" that serves small market segments, not being served by larger firms.

The objectives and strategies of competitors have to be well analyzed in order for Marketing Manager to know how to position its firm. The objective may be growth, profit, market share, global competitiveness and others. The competitive strategies to gain further insight is by classifying firms by the roles they play in the target market as market leader, market challenger, market flower and market nichers as already stated. Small business fall in the realm of market nichers (Kotler and Keller, 2009).

Small business cannot meet up with' the fierce competition of larger ones, instead they have to avoid the strategies of larger companies and look beyond the boundaries of occupied markets of large companies. Kotler and Armstrong (2004) posited that though both large and small firms adopt market nicher strategies, nichers are often common among small firms with limited resources. Niche marketing are often adopted by firms that serve small market segments not served by larger Iinns. Kotler (2009) stated that these firms normally avoid competing with larger firms by targeting small market of little or no interest to larger ones. In some cases, large firms or leaders may choose 10 USC niching strategies for some of their business units or companies. This is called "smart mclung". "Such firms with low shares of the total market can be highly profitable by offering high value, charge a penile price, achieve lower cost, and shape a strong corporate culture and vision". Example. of smart niching is U.A.C, Nigeria manufacturing table water, branded "eva" and competing favourably with popular small or medium scale leading companies. It is therefore suggested that smart-niching should be regulated in some businesses in Nigeria for survival of SMEs.

Another strategy is for firms - large and especially small companies can adopt "multiple niching". This involves developing two or more niches and by so doing increases its chances for survival. However, multiple niching is dangerous with too many niches. The cell photo industry, for example, is experiencing phenomenal growth because of multiple-niching but is however facing fierce competition in the industry.

Customization is another profitable way of dealing with customers by small businesses. This is also called "individual marketing" which deals with the special "needs and preferences of individual customers". This originally started with the tailor custom-made suits, the cobbler designed shoes and cabinet-made furniture for individual customer from their orders. In modern times, with technologies, many large companies are now involved in "mass customization" in such products as electronic credit cards and body scanning machines (Kotler and Armstrong 2004).

On the whole, for SMEs to have competitive advantage in a fierce competitive marketing environment, they have to achieve market growth through market niching of focusing and customization, which are the precincts of "blue-ocean strategy".

\section{Blue-Ocean Strategies}

SMEs are often the main driver for a country's economic growth. But as the number of SMEs increases, competition increases, which often result to a decrease in prices, customer base or both. This in turn will erode existing profits, creating less incentive for people to start SMEs, the greater the competition, resulting in a slower rate of growth for SMEs. To encounter the increasing competition, firms are usually pushed to lower prices, increase promotion of their products, emphasis on their competitive advantages, improve their product, add new distribution channels and also improve their internal processes. The challenge is to counter competition when the firm still has the financial resources to do so. Otherwise, once the pressure of competition sufficiently erodes the SMEs profits, it will no longer have resources to encounter the competition and will have to exit the market. Competing in overcrowded industries is no way to sustain high performance. The real opportunity is to create Blue Ocean of uncontested market price

The basic strategies for building competitive advantage by companies were well enunciated by Porter (1990). He suggested four basic competitive positioning strategies that companies can follow — three winning ones and one loosing one. The three winning strategies include overall cost leadership of achieving lowest cost 
production and distribution, differentiation of product lines and marketing programmes, as the class leaders in the industry and focus on serving a few market segments for monopoly and high profits. The loosing strategy is the "middle-of-the roaders", who do not pursue clear strategies in terms of cost, perceived value and serving market segments. They try to be good on all strategies counts, but end up being not very good at anything".

It has been discovered that of all the competitive strategies, the focus strategy or niching, which is a "blue-ocean strategy" is more suited for small businesses Blue-Ocean thinking" is defined by Chan-Kirn and Mauborgne (2005) as "creating products and services for which there are no direct competitors". Their belief is that "instead of searching within the conventional boundaries of industry competition, managers should look beyond those boundaries to find unoccupied market positions that represent real value innovation". They also believed that too many firms engage in "red ocean thinking, seeking bloody, "head-to-head" battles with competitors, based largely on incremental improvements in cost, quality, or both.

The other elements in their analyses of blue-ocean strategies are: designing creative business ventures to positively affect both company's cost structure and its value proposition to customers, and offering reliable but fun and convenience service at low cost. For example, Southwest Airlines created an airline that offers reliable, fun and convenient low cost service.

Manborne (2005) proposed four crucial questions for marketers to ask themselves in guiding and creating value innovation:

i. Which of the factors that our industry takes for granted should we eliminate?

ii. Which factors should we reduce well below the industry's standards?

iii. Which factors should we raise well above the industry's standard?

iv. Which factors should we create that the industry has never offered?

They maintain that the most successful blue-chip thinkers took advantage of all the four platforms on which value innovation can take place.

Another blue-ocean strategy is "market-nicher" strategies. As already stated, smaller firms avoid competiting with larger firms by targeting small markets of little or no interests to large ones. The danger is that niching easily weakens, as larger firms use their departments and units to niche in few markets including the ones used by the smaller firms. This is why the smaller firms are advised to take to multiple, instead of single niching, for survival if they have enough resources. Koiler and Keller (2009).

\section{Sme Investment Opportunities In Nigeria}

Many business analysts have agreed that investment opportunities especially for small-scale businesses abound in Nigeria. Toure (2008) featured good analysis on the conducive Nigeria's environment for business and opportunities for investment in big, medium or small business in the Round Table Conference on the Global Economic Crisis in December, 2008. Toure specifically acknowledged that "if you do business in Nigeria, you record good return on your investment".

I bough the security situation at present (2012) is far worse than that of year 2008, the foreign investors in Nigeria, especially, the big Oil Companies (MNGs) have continued to remain and be "eating fat" on the huge profits from their business.

Azeez (2008) in his comments, among others, in the same Conference agreed that:

i. Nigerian economy is one of the fastest growing economies (in telecommunications) in Africa and the World, with 57 percent of the West African mobile phone users.

ii. Nigeria is an investment haven with countless and lucrative opportunities, including oil and gas. Solid mineral is also another sector with great opportunities, with bitumen, talc, salt springs, bentorite, genstone, and many others.

The implication of these analyses from the above experts is that there are abundant opportunities for investment by small business in oil and gas, solid minerals, agriculture and tourism, in addition to telecommunication sub-sector.

In addition, a list of small-scale investment opportunities compiled by Akinyemi (1988) in the periodical of the Nigerian Association of Small-Scale Industrialists also lend credence to the abundant investment opportunities in which small business can apply "blue-ocean strategies" and achieve high growth and large market share. There are:
a) Agricultural and Agro-Allied Industry,
b) Leather industry,
c) Paper products,
d) Textile and Associated Industry,
e) Metal and Engineering,
f) Chemical and Allied Groups,
g) (Wood and Woodwork,
h) Traditional Craft and Cultural Heritage, and 
i) Service Enterprise.

The above analyses show that there are many unoccupied and uncontested markets for small businesses to explore. Doing this by small business, requires effective competitive market strategies of "blue - ocean strategy", which has paid for many Emerging Economies such as, Japan, South Korea, India and China and others. The Federal Government of Nigeria and its Central Bank will need to massively empower SMEs through substantial financing and possibly linking the SMEs with Foreign DiiLi Investment (FDI).

\section{Conclusions And Recommendations}

This paper concludes that blue-ocean strategies, in form of niching offers the SMEs opportunities to compete and possibly make more profits than its larger competitors and possibly meet tip with global competitiveness. In addition, many companies that starts as nichers to get a foot hold in the market against the larger and more resourceful competitors and later experience high growth and grow into broader competitors. The low cost of setting up shops in the internet today makes it more profitable for small niches and they are realizing riches from serving small niches on the web, while some internet giants have yet to realize consistent profits. Finally, Nigeria has many unoccupied an uncontested market for SMEs, which they can easily explore and manage through blue - ocean strategies to achieve high growth.

It is therefore recommended that the Federal government, its Central Bank (CBN) and other agents should engage in massive sectoral funding of SMEs in the country to enable investors to explore abundant opportunities in the country and manage them by employing modern management techniques such as blueocean strategies exposed in this study, to achieve superior performance, high growth and global competitiveness.

\section{References}

[1]. Akinyemi, A.O. (1988), The Nigeria Entrepreneur, June,. Nigerian Association of Small Scale Industrialists.

[2]. Azeez, B. (2008), Round Table Conference January, on the Global Economic Crisis, Lagos, Nigeria.Bankers' Committee, Nigeria, 2009.

[3]. Chan Kun, W. and Mauborgne, R. (2005), Blue-Ocean Strategy: How to Creat

[4]. UncontestedMarket Space and Make the Competition Irrelevant, (Cambridge, M.A. Harvard Business SchoolPress). Davidson, P. Entrepreneurs Reap Riches from Net Niches, US.A. Today, July, 2002.

[5]. Kotler, P. and Armstrong, G. (2004), Principles of Marketing (Person Education mc; Singapore Second Indian Reprint), P.253.

[6]. Kotler, P and Keller, K.N. (2009), Marketing Management, (Pearson International, 13th Edition), P.

[7]. Waswa, Balunywa, (2009), Makerere University Business School, Kampala, Uganda.

[8]. Porter, Michael (1990), Competitive Strategy, Techniques for Analyzing Industries and Competitors, (Free Press).

[9]. Toure, H. (2008), Round Table Conference, January, on the Global Economics Crisis,Lagos, Nigeria.

[10]. Weintraub, Arlene (2001) Chairman of Board, Business Week, May 28, P.94. 